\title{
IRF4 Gene
}

National Cancer Institute

\section{Source}

National Cancer Institute. IRF4 Gene. NCI Thesaurus. Code C18430.

This gene is involved in the regulation of B-cell differentiation and proliferation. It also plays a role in mediating the proliferation of mitogen-stimulated T cells. 